\title{
CHANGES IN BLOOD MORPHOLOGY AND CHOSEN BIOCHEMICAL PARAMETERS IN ULTRA-MARATHON RUNNERS DURING A 100-KM RUN IN RELATION TO THE AGE AND SPEED OF RUNNERS
}

\section{ZBIGNIEW JASTRZĘBSKI ${ }^{1}$, MALGORZATA ŻYCHOWSKA ${ }^{1}$, MARIA JASTRZĘBSKA², KRZYSZTOF PRUSIK ${ }^{1}$, KATARZYNA PRUSIK ${ }^{1}$, JAKUB KORTAS ${ }^{1}$, WOJCIECH RATKOWSKI ${ }^{1}$, ANNA KONIECZNA ${ }^{1}$,} and ŁUKASZ RADZIMIŃSKI ${ }^{1}$

\author{
${ }^{1}$ Gdansk University of Physical Education and Sport, Gdańsk, Poland \\ Department of Tourism and Recreation \\ ${ }^{2}$ Medical University of Gdańsk, Gdańsk, Poland \\ Department of Medicine
}

\begin{abstract}
Objectives: The objective of the study was to reveal morphology, electrolyte and chosen biochemical parameters in terms of health risk in runners in reference to their age and running speed in the case of running a distance of $100 \mathrm{~km}$, which occur after $12 \mathrm{~h}$ or $24 \mathrm{~h}$ of recovery. Material and Methods: Fourteen experienced, male, amateur, ultra-marathon runners, divided into two age and two speed groups took part in the $100-\mathrm{km}$ run. Blood samples for analyses indexes were collected from the ulnar vein just before the run, after $25 \mathrm{~km}, 50 \mathrm{~km}, 75 \mathrm{~km}$ and $100 \mathrm{~km}$, as well as $12 \mathrm{~h}$ and $24 \mathrm{~h}$ after termination of the run. Results: The sustained ultramarathon run along with the distance covered $(\mathrm{p}<0.05)$ caused an increase in myoglobin ( $\max 90$-fold), bilirubin ( $\max 2.8$-fold) and total antioxidant status (max 1.15-fold), which also continued during the recovery. Significant changes in the number of white blood cells were observed with each sequential course and could be associated with muscle damage. The electrolyte showed changes towards slight hyperkalemia, but no changes in natrium and calcium concentrations. There were no significant differences between the age and speed groups for all the parameters after completing the $100-\mathrm{km}$ run as well as after $12 \mathrm{~h}$ and $24 \mathrm{~h}$ of recovery. Conclusions: Considering changes in blood morphology and chosen biochemical parameters in ultra-marathon runners during a 100-km run it can be stated that such an exhausting effort may be dangerous for human health due to metabolic changes and large damage to the organs. Negative metabolic changes are independent of age of an ultramarathon runner and occur both in younger ( $32 \pm 5.33$ years) and older participants (50.56 \pm 9.7 years). It can be concluded that organ damage and negative metabolic changes during a 100-km run occur similarly in participants less experienced as well as in well trained runners. Int J Occup Med Environ Health 2016;29(5):801-814
\end{abstract}

Key words:

Liver damage, Muscle fatigue, Long distance running, Age and speed differences, Total antioxidant status, Ultra-marathon

Received: February 16, 2015. Accepted: November 12, 2015.

Corresponding author: Z. Jastrzębski, Gdansk University of Physical Education and Sport, Department of Tourism and Recreation, Górskiego 1, 80-336 Gdańsk, Poland (e-mail: zb.jastrzebski@op.pl). 


\section{INTRODUCTION}

Fast development of civilization and higher living standards caused reduction of physical activity in the population. This process regards highly developed countries as well as the ones that are still developing. Therefore, the aim of hazard prevention connected with civilization is promotion of physical activity. According to this trend, a health-related fitness (H-RF) concept has been proposed by Bouchard et al. [1] and Skinner and Oja [2]. This concept puts emphasis on the health aspect of physical activity. It is a significant approach in terms of individuals and society as a whole because the number of old people is continuously increasing, especially in highly developed countries.

As this idea becomes more and more popular, the number of active people involved in recreation is increasing. Some of them take up extreme forms of recreation such as winter baths, mountaineering, marathons or ultra-marathons. However, such extreme forms involve health risks. After a marathon run, hospitalisation or even death can occur [3].

Statistics reported by Mathews et al. [4] reveal 28 fatalities that occurred during the run or within $24 \mathrm{~h}$ after termination of marathon races organised in the USA from 2000 to 2009 [5]. Deaths occurred mainly among young participants $(<45$ years old). Therefore, scientists are increasingly interested in the issue of the body's response to the extreme effort performed by amateurs, especially economy of the use of energy sources [5-8], relationship between running speed and maximal oxygen uptake $\left(\mathrm{VO}_{2 \max }\right)$ [9-12], changes of biochemical indicators in the blood [4,13-15] that indicate damage to skeletal muscles and organs [16-24] and recently, advantages and threats of such an activity in terms of health [25-29].

Thus, it seems that monitoring of the reaction of the body by observing changes in blood indicators during a marathon run, should be a standard procedure. Most commonly used indicators of health risk in marathon runners during the run and recovery are those that show damage to the organs (bilirubin, aspartate aminotransferase (AST), alanine aminotransferase (ALT), lactate dehydrogenase $(\mathrm{LDH}))$ or cardiac and skeletal muscles (LDH, creatine kinase (CK) and C-reactive protein (CRP)) $[16,17,19,20,25,26,30]$. In addition, myopathy poses a threat to marathon runners because it can be the first symptom of Huntington's disease. Furthermore, such an effort has an adverse effect on arteries, which could lead to a sudden cardiac death (SCD) in males, especially those $>38$ years old $[21,22]$. However, the research literature provides different findings regarding the effect of such an effort on the runners [18,30]. Thus, there is no consensus whether such an effort supports health or which factors determine damage to the organs.

Previous studies do not provide a clear answer to the question which factor: the age or running speed, determine damage of the organs in marathon runners. Therefore, in this study, 3 main questions were answered:

1. Are significant metabolic changes dangerous to a runner's health during a $100-\mathrm{km}$ run?

2. Is metabolic response of the organism to the extreme effort related to a runner's age?

3. Does running speed determine the extent of damage to the organs or metabolic changes?

\section{MATERIAL AND METHODS}

\section{Participants}

Fourteen males volunteered for the study (age: $43.36 \pm 11.83$ years, height: $175.29 \pm 6.98 \mathrm{~cm}$, weight: $72.12 \pm 7.36 \mathrm{~kg}$ ). All the subjects were experienced, amateur, ultra-marathon runners who signed an informed consent form prior to the study. The subjects were divided into 2 age groups: younger (group A: $32 \pm 5.33$ years) and older (group B: $50.56 \pm 9.7$ years) groups, and 2 groups according to their running speed: faster (group $\mathrm{A}_{1}: 2.81 \pm$ $0.18 \mathrm{~m} / \mathrm{s}$ ) and slower (group $\mathrm{B}_{1}: 2.43 \pm 0.12 \mathrm{~m} / \mathrm{s}$ ) groups. The selection resulted in having 7 subjects in each group. 
There were significant differences revealed for the age of the subjects ( $p=0.0009)$ and running speed $(p=0.0004)$. We asked the participants not to consume any sport supplements (vitamins or minerals) for a month preceding the study. However, on the basis of a previously conducted interview with the subjects, it was found that none of them applied regular supplementation. Usually they ran without a specific training plan 5-6 times a week covering each time a distance of $15-20 \mathrm{~km}$ at a moderate intensity (generally below the anaerobic threshold).

All the subjects had valid medical cards and received medical supervision during the experiment. The study protocols received an ethical approval (KB-26/12) from the Ethical Committee of Regional Medical Chamber in Gdańsk (Poland).

\section{Trial design}

The 100-km run started at 7:30 a.m. and finished (for the last runner) at 7:38 p.m. The subjects repeatedly ran a designated route of $3300 \mathrm{~m}$. The altitude was $20 \mathrm{~m}$ above the sea level, and the altitude differences did not exceed $3 \mathrm{~m}$. The running surface was made of asphalt. Temperature during the run ranged from $4-7^{\circ} \mathrm{C}$, the wind speed was $0.7-1.4 \mathrm{~m} / \mathrm{s}$ and humidity was $83-89 \%$.

The shortest time required to complete the $100-\mathrm{km}$ run was $9 \mathrm{~h}$ and $11 \mathrm{~min}$, and the longest time was $12 \mathrm{~h}$ and $8 \mathrm{~min}$ (the time did not encompass 1-min breaks for blood sample collections). The run times and break times between the courses were measured with a stopwatch (Timex, Switzerland), and the time results after each turn were shown on a board at the starting line. Running speed was measured individually every $25 \mathrm{~km}$. Each participant was dressed in trainers, a T-shirt, a tracksuit (a cotton sweatshirt and pants), gloves and a cap (made of natural fibres).

The participants' individual clothing preferences were accepted. Each of the runners was equipped with a portable heart rate monitor (Polar Electro Oy, Finland), which measured heart rate in 5-s intervals. Twelve hours before the experiment, the subjects ate supper. After a night of rest, they ate a light breakfast of their choice at 6:30 a.m. During the run, the runners nourished themselves with prepared food and drinks served at special stands. The food included water with low mineral content, high-energy drinks, sandwiches with cheese or ham, highenergy bars and bananas.

Blood samples analysed for indexes of liver and muscle damage, expressed as the percentage change in the blood plasma volume, were calculated following the indexes of Dill and Costill [9]. Reference values for the tested indexes were: red blood cells (RBC) (4.4-6.3×10 12/1), hemoglobin (HGB) (14$18 \mathrm{~g} / \mathrm{dl}$ ), hematocrit (HCT) (37-47\%), mean corpuscular volume (MCV) (80-97 fl), mean corpuscular hemoglobin $(\mathrm{MCH})$ (28-34 pg), mean corpuscular hemoglobin concentration (MCHC) (32-36 g/dl), blood platelets (PLT) $\left(140-440 \times 10^{9} / 1\right)$, white blood cells (WBC) $\left(4-11 \times 10^{9} / 1\right)$, erythrocyte sedimentation rate $($ ESR $)(<10 \mathrm{~mm} / \mathrm{h})$, sodium $\left(\mathrm{Na}^{+}\right)(135-147 \mathrm{mmol} / \mathrm{l})$, potassium $\left(\mathrm{K}^{+}\right) \quad(3.7-5.3 \mathrm{mmol} / \mathrm{l})$, calcium $\left(\mathrm{Ca}^{+}\right)$ (1-1.32 mmol/l), chloride $\left(\mathrm{Cl}^{-}\right)$(98-108 mmol/l), mioglobin $(10-46 \mu \mathrm{g} / \mathrm{l})$, total antioxidant status (TAS) (1.3$1.77 \mathrm{mmol} / \mathrm{l})$, and bilirubin $(0.3-1.0 \mathrm{mg} / \mathrm{dl})$ [30]. Blood samples were collected from the ulnar vein just before the run, after $25 \mathrm{~km}, 50 \mathrm{~km}, 75 \mathrm{~km}$, and $100 \mathrm{~km}$, as well as $12 \mathrm{~h}$ and $24 \mathrm{~h}$ after the end of the run. Biochemical analysis was conducted by the use of the A15 analyser (Biosystems S.A., Spain).

\section{Statistical analysis}

The results are expressed as mean values and standard deviations. The Shapiro-Wilk test was applied to assess homogeneity of dispersion from the normal distribution. The Levene test was used to verify homogeneity of variance. For homogenous results, an analysis of variance (ANOVA) for repeated measures and the post hoc honest significant 
difference (HSD) Tukey's test for equal sample sizes were performed to identify significantly different results.

For heterogeneous results, an ANOVA Friedman's test and right post hoc test were applied. The significance level was set at $p<0.05$. The results were analysed using Statistica 9.0 software (Statsoft, USA). Additionally, the d Cohen effect size (ES) was calculated to enable comparison of the results between the groups (older vs. younger, and faster vs. slower). For interpretation of the ES, the following criteria for the Cohen's $d$ were used: $\mathrm{ES} \leq 0.2$ (trivial); $0.2<\mathrm{ES} \leq 0.6$ (small); $0.6<\mathrm{ES} \leq 1.2$ (moderate); $1.2<\mathrm{ES} \leq 2$ (large); and ES $>2$ (very large) [31].

\section{RESULTS}

Running speed developed during the $100-\mathrm{km}$ run decreased along with the distance covered. During the last stretch $(76-100 \mathrm{~km})$, the running speed was significantly lower than during the $0-25 \mathrm{~km}$ or $26-50 \mathrm{~km}$ stretches. Together with the decrease in the running speed, the decrease in the mean heart rate (HR) and relative intensity of work were observed, especially between $75-100 \mathrm{~km}$. The $\mathrm{d}$ Cohen effect size was trivial $(0.2<\mathrm{ES} \leq 0.6)$ or small $(0.6<\mathrm{ES} \leq 1.2)$, independently of the criteria for grouping. However, moderate $(1.2<\mathrm{ES} \leq 2)$ differences were observed for HR; the group of faster runners showed lower values of HR during both the run and recovery at a relatively lower intensity of effort (percent of maximal heart rate $\left.-\% \mathrm{HR}_{\max }\right)$ (Table 1$)$.

\section{Changes in blood count}

No significant differences for the number of red blood cells and haemoglobin (HB) concentration, hematocrit or blood platelets during the run or recovery in the runners were found. Values of these indicators were within physiological norms during the whole experiment. Mean corpuscular volume, MCHC and MCH were stable during the run, and slightly increased during the recovery (within $24 \mathrm{~h}$ after termination of the run). The total number of white blood cells increased considerably $(\mathrm{p}<0.05)$ after $75 \mathrm{~km}$ of the run and this increase continued during the recovery. In addition, an increase in ESR was observed for HB, RBC and HCT was small $(0.6<\mathrm{ES} \leq 1.2)$ between the younger and older runners, and moderate $(1.2<\mathrm{ES} \leq 2)$ between the faster and slower runners (Table 2 and 3 ).

\section{Changes in electrolytes}

Concentration of sodium, calcium and chloride ions did not change significantly during the run. However, after the $24 \mathrm{~h}$ of recovery, a considerable increase in the concentration of these ions was observed. The differences between the groups were small $(0.6<\mathrm{ES} \leq 1.2)$ (Table 4 and 5).

\section{Changes of myoglobin and bilirubin}

The mean value of myoglobin increased along with the distance covered. Its mean concentration reached $100 \%$ of the physiological norm after $25 \mathrm{~km}$ of the run, and $300 \%$ after $100 \mathrm{~km}$ of the run. During the recovery, a decrease in myoglobin concentration was observed, and the highest rate was noted during the first $12 \mathrm{~h}$ of recovery $(\mathrm{p}<0.05)$. There were no statistically significant differences between the groups with reference to the age or running speed during both the run and recovery (Table 4 and 5). A considerable increase in bilirubin concentration was observed at about $75 \mathrm{~km}$, and it was the value that exceeded the norm and it was present even after $24 \mathrm{~h}$ of recovery. High standard deviation values showed a high individual variation of indicators of muscles and liver damage in reference to the age or running speed and ranged from trivial to small (ES $\leq 0.2$ (trivial); $0.2<\mathrm{ES} \leq 0.6$ (small)) (Table 4 and 5).

A high individual diversity in the marathon runners for the myoglobin concentration was observed. In some subjects the values did not exceed the norm, while in others they reached $2500 \mathrm{mg} / \mathrm{ml}$. Most subjects showed an increase in bilirubin concentration with the distance covered 

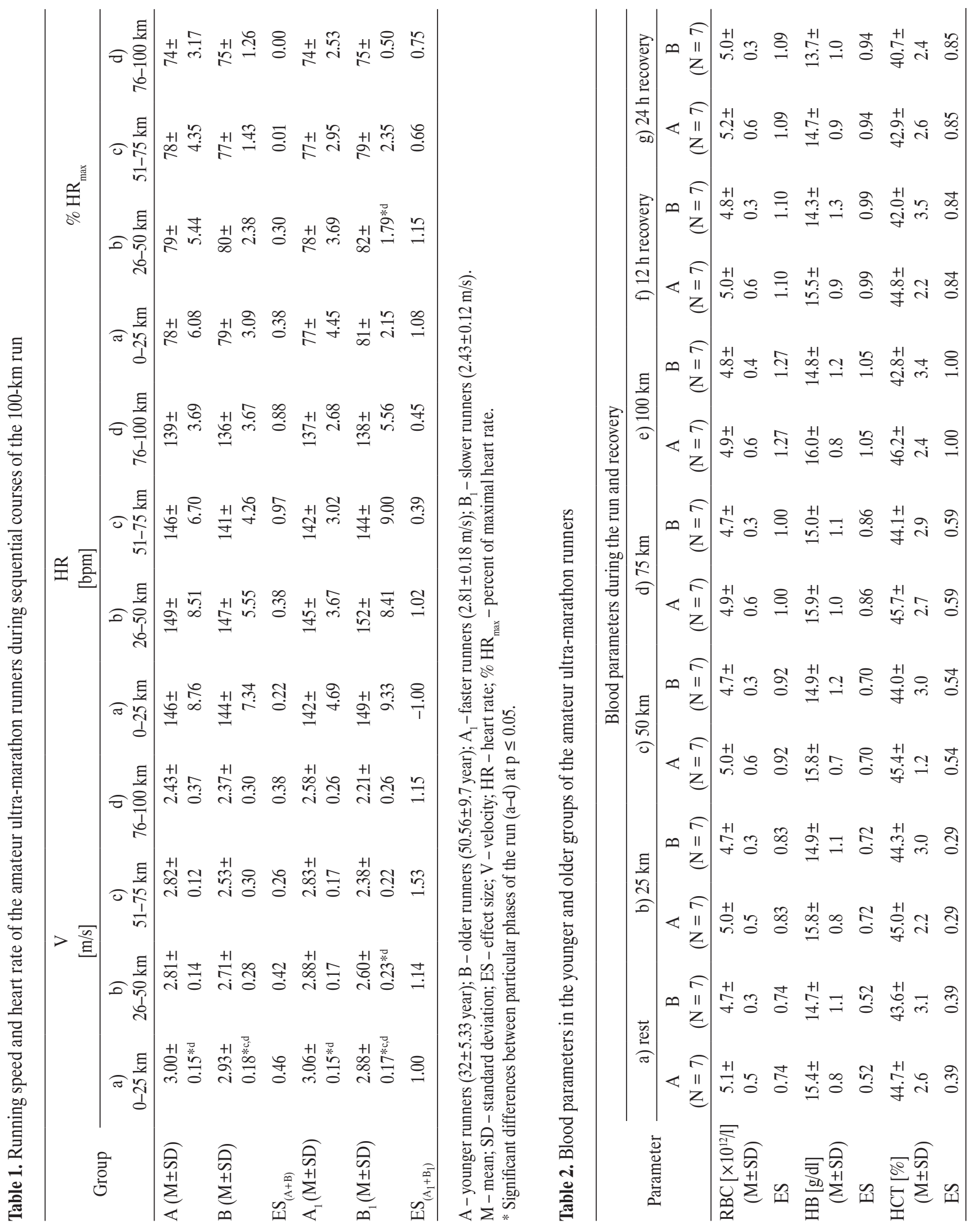







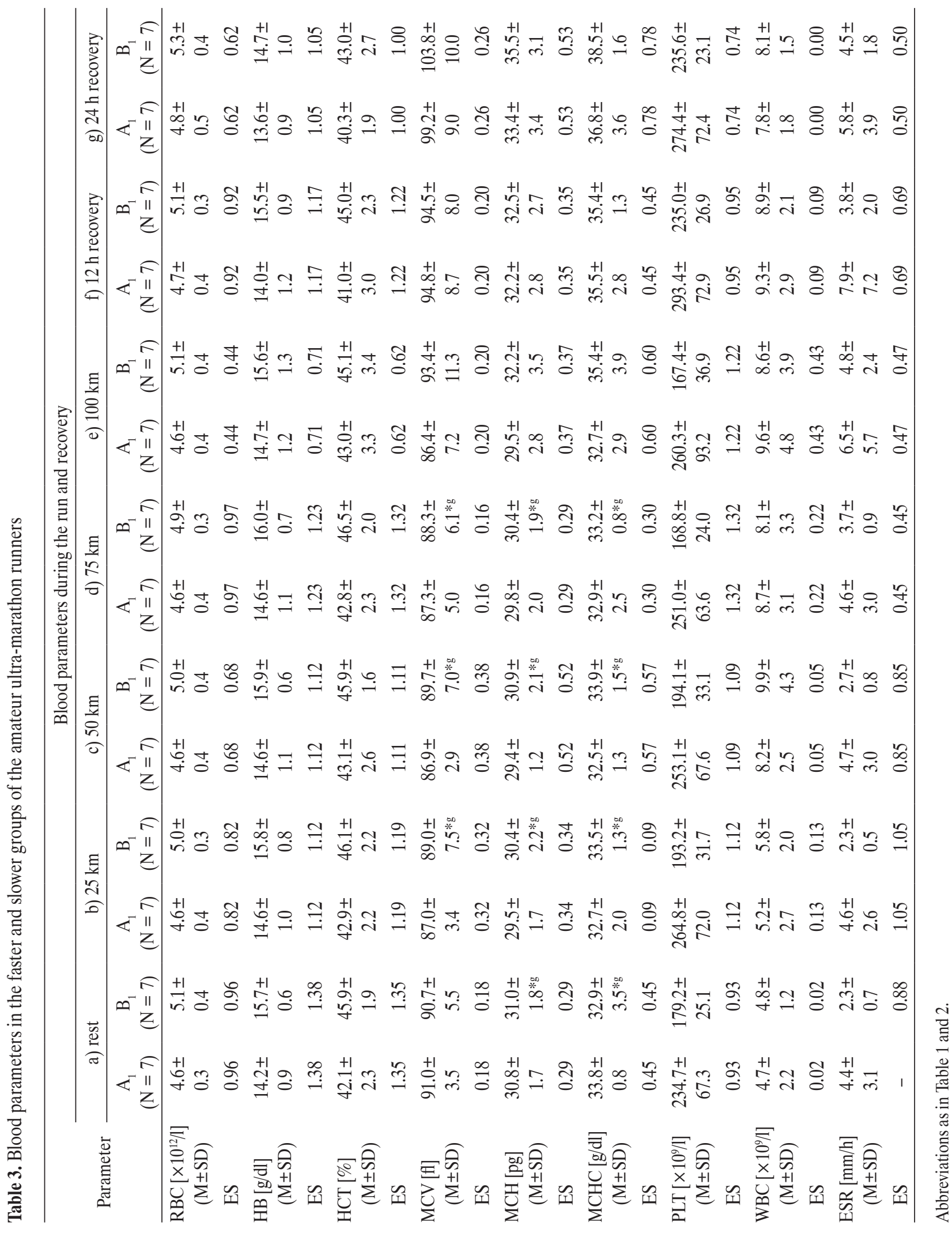




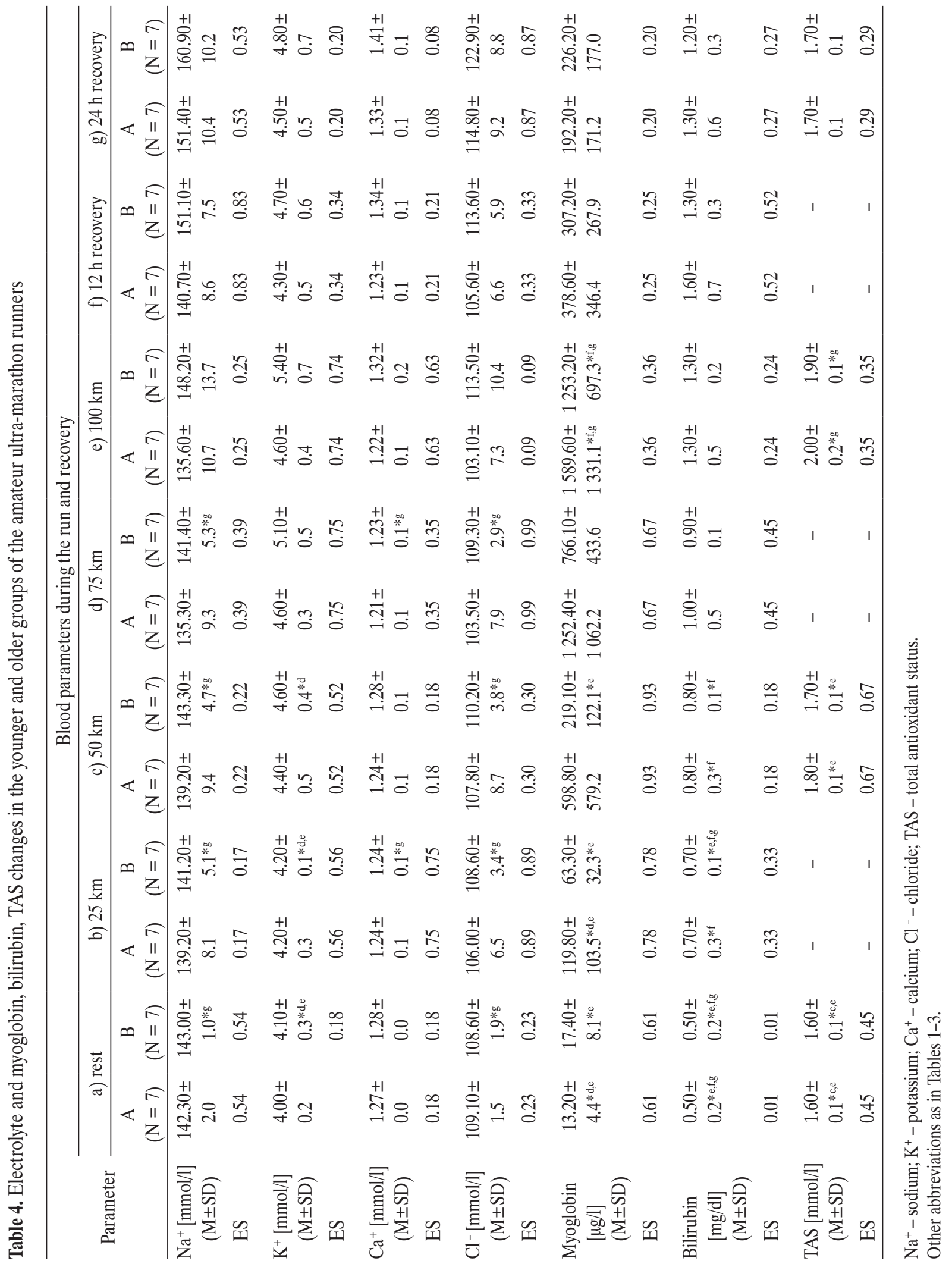




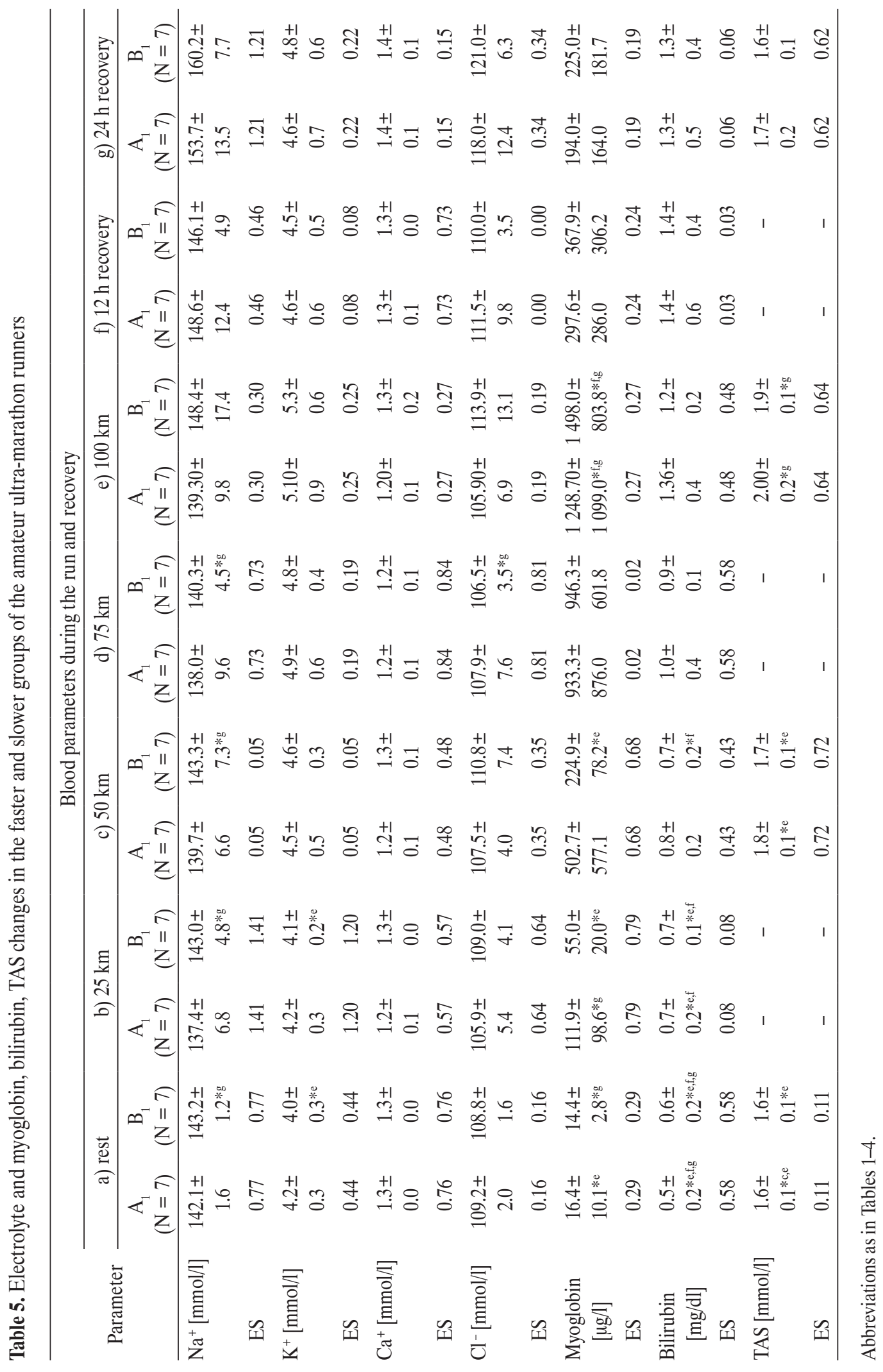



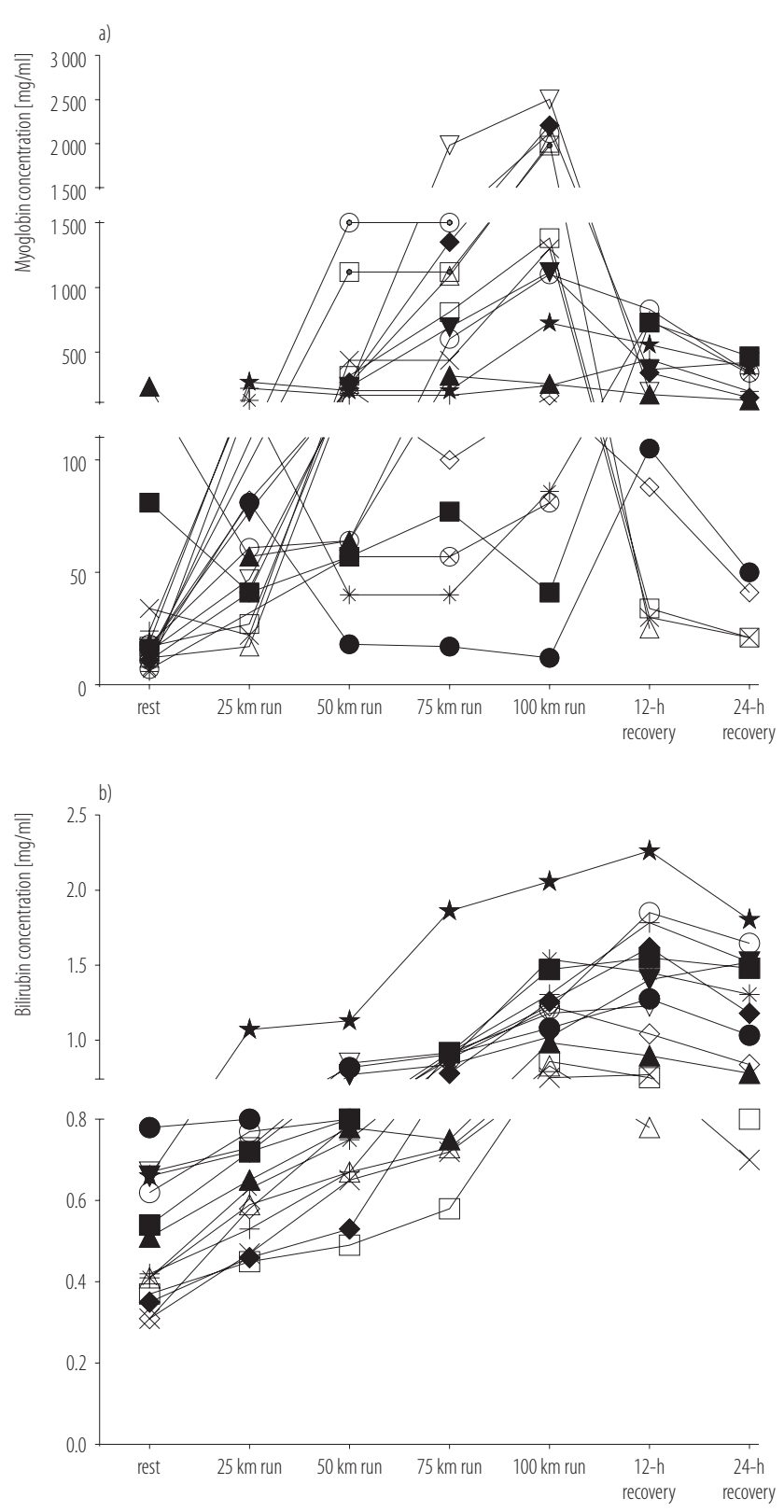

Fig. 1. Individual changes in a) myoglobin and b) bilirubin concentrations in amateur ultra-marathon runners $(\mathrm{N}=14)$ during the $100-\mathrm{km}$ run as well as after $12 \mathrm{~h}$ and $24 \mathrm{~h}$ of recovery

and up to the 12-h mark during the recovery. Then, a decrease was registered. Values within the norm were found only in one subject. No relationship of these indicators with reference to the age or running speed were revealed (Figure 1).

\section{TAS changes}

The changes of antioxidant status showed the same trends for all the subjects. Total antioxidant status value was increasing proportionally to the distance covered, and exceeded the norm. During the 24-h recovery, the values almost reached the reference values. No statistically significant differences between the groups with reference to the age or running speed were found (Table 4 and 5).

\section{DISCUSSION}

Despite the fact that many scientists show research interests in extreme running, the results of the studies often differ. It may result from the various age of the subjects, sports experience, amateur or professional status and including or excluding changes of blood plasma volume while interpreting the results. In our study, apart from biochemical changes in the runners caused by the $100-\mathrm{km}$ run, we also examined variation with reference to the age and running speed of the subjects.

The younger subjects developed slightly higher speeds. Interestingly, intensity of work expressed as $\% \mathrm{HR}_{\max }$ was lower in the group that developed higher running speeds. It can be concluded that this group developed a better adaptation to a long-lasting effort. Running speed decreased along with each $25 \mathrm{~km}$ stretch in all the subjects (Table 1). The mean running speed value during the whole $100-\mathrm{km}$ distance was $8.33 \mathrm{~km} / \mathrm{h}$, which is in line with the results revealed by Kłapcińska et al. [29].

Parameters of the blood counted both during the run and recovery did not exceed the reference data. No statistically significant changes in $\mathrm{HB}, \mathrm{HCT}, \mathrm{RBC}, \mathrm{MCH}, \mathrm{MCV}$, $\mathrm{MCVC}$ and blood platelets were found during either the run or the recovery. Kłapcińska et al. [29] and Waśkiewicz et al. [28] have reported similar findings. However, Wu et al. [27] have observed a decrease in RBC related to haemolysis [32] and damage caused by reactive oxygen species (ROS) [33] that occurred between the second and ninth day of recovery after termination of a half-marathon. 
There was no increase in haemolysis in our study, and the increase of TAS was a protective reaction against harmful effects of ROS. The highest and most statistically significant changes (Table 2 and 3 ) for WBC were observed in all the groups, similarly to the findings reported by $\mathrm{Wu}$ et al. [27]. The highest number of white blood cells in the runners was found after $12 \mathrm{~h}$ of recovery (1.9-fold of resting value). However, a considerable increase of WBC was observed during the run, especially on the last stretch $75-100 \mathrm{~km}$ independently of the age or running speed of the participants. A relatively low resting value of WBC is probably related to the adaptation to a long-lasting effort, and the increase of white blood cells may be caused by their passing to blood vessels as well as their increased production [32]. The $\mathrm{d}$ Cohen index, counted between the indexes mentioned above and the age or running speed of the subjects was low (Table 2 and 3 ).

Changes in the level of electrolytes in marathon runners are one of the most significant factors limiting the run of high intensity. In the presented study, the subjects performed a 100-km ultra-marathon, and the results include percentage changes in plasma volume (\% $\%$ PV). Probably this is the reason why the results of electrolytes in our subjects in all the groups show a gradual increase in potassium and a decrease in sodium and chloride concentration during the run. Moreover, during the recovery, a decrease in sodium and chloride concentration was observed.

One of the reasons for such changes in the runners could be sweating, as the increase in potassium ion concentration is not an effect of the increase in permeability of the cell membrane, but results from the active transport of $\mathrm{K}^{+}$ions by sodium-potassium adenosine triphosphatase $\left(\mathrm{Na}^{+} / \mathrm{K}^{+}\right.$-ATPase) $[29,34,35]$. Changes in calcium concentration did not reach significance during the experiment. In addition, trivial or small differences were stated for electrolytes with reference to the age or running speed of the subjects during the 100-km run (Table 4 and 5).
The available scientific literature describes the effect of high-intensity exertion on the increase of oxygen consumption and production of its reactive forms [36-38]. The increase in ROS production along with the covered distance caused an increase in TAS in blood plasma and lasted until termination of the run. Our results are in line with the findings reported by Kłapcińska et al. [29], who have noticed a maximal increase in TAS after $12 \mathrm{~h}$ of ultramarathon running. This effect is a response of the organism to the developing oxidative stress. Results of our study show a complete compensation of the increased oxidative stress by the antioxidative defence system in the subjects. Therefore, it can be suggested that the runners developed adaptation to the long-distance run during the training process regardless of their age or running speed.

Statistically significant differences for the bilirubin and myoglobin concentration were found during the rest and after the $100-\mathrm{km}$ run in all the groups. The rate of the decrease in myoglobin concentration in blood plasma during the recovery was lower than the rate of the decrease in bilirubin. Our results regarding myoglobin concentration as a significant index of muscle damage are in line with the findings reported by Lippi et al. [15], who have observed a considerable increase in myoglobin concentration after termination of a half-marathon, which continued up to $24 \mathrm{~h}$ of recovery. Moreover, we observed considerable differences in this indicator among the runners (Figure 1). Similar results have been reported by Wu et al. [27], who have observed a considerable increase in these indexes even after $48 \mathrm{~h}$ of recovery, which was fully balanced only after nine days of recovery. Our results show considerable differences in myoglobin and bilirubin concentrations during the experiment. However, low effect size was stated between the concentration of these indexes and the age or running speed.

Concentration of bilirubin increased significantly after running $50 \mathrm{~km}$. During the 24-h recovery, bilirubin concentration increased, and did not reach the reference 
value $(>1)$ in 13 out of 14 subjects (Figure 1). Changes in sodium, potassium, calcium and chloride as well as in bilirubin concentration occurred after the run and during the recovery.

During the recovery electrolyte imbalance and liver damage appeared as consequences of the 100-km run. Therefore, we suggest, that control of these parameters during recovery is necessary.

Results of our study indicate that the $100-\mathrm{km}$ run elicited negative physiological changes in the bodies of the runners. Independently of the age and running speed, metabolic changes were similar in each phase of the run. These changes affected skeletal muscles and inner organs as well, and individual differences seemed to be significant. Previous studies have shown similar results, however, the authors have not considered the age and running speed of the participants.

Earlier research as well as our study did not involve large groups of ultramarathon runners. Therefore, validity of statistical analyses may be problematic. However, the number of people taking part in such extreme efforts as a $100-\mathrm{km}$ run is very limited, and calculating the $d$ Cohen effect size should reduce the possibility of potential error.

\section{CONCLUSIONS}

Considering changes in blood morphology and chosen biochemical parameters in ultra-marathon runners during a $100-\mathrm{km}$ run, it can be stated that such an exhausting effort may be dangerous for human health due to metabolic changes and large damage to the organs.

Negative metabolic changes are independent of the age of an ultramarathon runner and occur both in younger ( $32 \pm 5.33$ years) and older participants (50.56 \pm 9.7 years). It can be concluded that organ damage and negative metabolic changes during a $100-\mathrm{km}$ run occur similarly in participants who are less experienced and in those who are well trained runners.

\section{REFERENCES}

1. Bouchard C, Stephard JR, Stephens T, Sutton JR, McPherson BD. Exercise, fitness, and health: A consensus of current knowledge. Champaign (IL): Human Kinetics; 1990.

2. Skinner JS, Oja P. Laboratory and field tests for assessing health-related fitness. In: Bouchard C, Shephard RJ, Stephens T, editors. Physical activity, fitness, and health. Champaign (IL): Human Kinetics; 1994. p. 160-79.

3. Ayus JC, Varon J, Arieff AI. Hyponatremia, cerebral edema, and noncardiogenic pulmonary edema in marathon runners. Ann Intern Med. 2000;132(9):711-4, http://dx.doi. org/10.7326/0003-4819-132-9-200005020-00005.

4. Mathews SC, Narotsky DL, Bernholt DL, Vogt M, Hsieh Y-H, Pronovost PJ, et al. Mortality among marathon runners in the United States, 2000-2009. Am J Sports Med. 2012;40(7): 1495-500, http://dx.doi.org/10.1177/0363546512444555.

5. Brancaccio P, Maffulli N, Limongelli FM. Creatine kinase monitoring in sport medicine. Br Med Bull. 2007;81-82: 209-30, http://dx.doi.org/10.1093/bmb/ldm014.

6. Burr JF, Bredin SS, Phillips A, Foulds H, Cote A, Charlesworth S, et al. Systemic arterial compliance following ultramarathon. Int J Sports Med. 2012;33(3):224-9, http://dx.doi. org/10.1055/s-0031-1297956.

7. Castell LM, Poortmans JR, Leclerq R, Brasseur M, Duchateau J, Newsholme EA. Some aspects of the acute phase response after a marathon race, and the effects of glutamine supplementation. Eur J Appl Physiol Occup Physiol. 1997;75:47-53, http://dx.doi.org/10.1007/s004210050125.

8. Chatzinikolaou A, Fatouros IG, Gourgoulis V, Avloniti A, Jamurtas AZ, Nikolaidis MG, et al. Time course of changes in performance and inflammatory responses after acute plyometric exercise. J Strength Cond Res. 2010;24(5):1389-98, http://dx.doi.org/10.1519/JSC.0b013e3181d1d318.

9. Dill DB, Costill DL. Calculation of percentage changes in volumes of blood, plasma, and red cells in dehydration. J Appl Physiol. 1997;37(2):247-8.

10. Howley ET, Franks BD. Health fitness instructor's handbook. Champaign (IL): Human Kinetics; 1997. 
11. Kim HJ, Lee YH, Kim CK. Biomarkers of muscle and cartilage damage and inflammation during a $200 \mathrm{~km}$ run. Eur J Appl Physiol. 2007;99:443-7, http://dx.doi.org/10.1007/ s00421-006-0362-y.

12. Kim HJ, Lee YH, Kim CK. Changes in serum cartilage oligomeric matrix protein (COMP), plasma $\mathrm{CPK}$ and plasma hs-CRP In relation to running distance in a marathon $(42.195 \mathrm{~km})$ and an ultra-marathon $(200 \mathrm{~km})$ race. Eur J Appl Physiol. 2009;105:765-70, http://dx.doi.org/10.1007/ s00421-008-0961-x.

13. Kosinski CM, Schlangen C, Gellerich FN, Gizatullina Z, Deschauer M, Schiefer J, et al. Myopathy as a first symptom of Huntington's disease in a marathon runner. Mov Disord. 2007;22(11):1637-40, http://dx.doi.org/10.1002/ mds.21550.

14. Kratz A, Lewandrowski KB, Siegel AJ, Chun KY, Flood JG, van Cott EM, et al. Effect of marathon running on hematologic and biochemical laboratory parameters, including cardiac markers. Am J Clin Pathol. 2002;118:856-63, http:// dx.doi.org/10.1309/14TY-2TDJ-1X0Y-1V6V.

15. Lippi G, Schena F, Montagnana M, Salvagno GL, Banfi G, Guidi GC. Significant variation of traditional markers of liver injury after a half-marathon run. Eur J Intern Med. 2011;22(5):36-8, http://dx.doi.org/10.1016/j.ejim. 2011.02.007.

16. McKenzie DC, Rhodes EC, Stirling DR, Wiley JP, Dunwoody DW, Filsinger IB, et al. Salbutamol and treadmill performance in non-atopic athletes. Med Sci Sports Exerc. 1983;15(6):520-2, http://dx.doi.org/10.1249/00005768198315060-00014.

17. Miles MP, Andring JM, Pearson SD, Gordon LK, Kasper C, Depner CM, et al. Diurnal variation, response to eccentric exercise, and association of inflammatory mediators with muscle damage variable. J Appl Physiol. 2008;104:451-8, http://dx.doi.org/10.1152/japplphysiol.00572.2007.

18. Noakes TD, Kotzenberg G, McArthur PS, Dykman J. Elevated serum creatine kinase $\mathrm{MB}$ and creatine kinase $\mathrm{BB}$ isoenzyme fractions after ultra-marathon running. Eur
J Appl Physiol Occup Physiol. 1983;52:75-9, http://dx.doi. org/10.1007/BF00429029.

19. Nuviala RJ, Roda L, Lapieza MG, Boned B, Giner A. Serum enzymes activities at rest and after a marathon race. J Sports Med Phys Fitness. 1992;32(2):180-6.

20. Rapoport BI. Metabolic factors limiting performance in marathon runners. PLoS Comput Biol. 2010;6(10):e1000960, http://dx.doi.org/10.1371/journal.pcbi.1000960.

21. Roberts WO, Roberts DM, Lunos S. Marathon related cardiac arrest risk differences in men and women. Br J Sports Med. 2013;47(3):168-71, http://dx.doi.org/10.1136/bjsports2012-091119.

22. Rosales XQ, Chu ML, Shilling C, Wall C, Pastores GM, Mendell JR. Fidelity of gamma-glutamyl transferase (GGT) in differentiating between skeletal muscle from liver damage. J Child Neurol. 2008;23:748-51, http://dx.doi. org/10.1177/0883073808314365.

23. Rumley AG, Pettigrew AR, Colgan ME, Taylor R, Grant S, Manzie A, et al. Serum lactate dehydrogenase and creatine kinase during marathon training. Br J Sports Med. 1985;19(3):152-9, http://dx.doi.org/10.1136/bjsm.19.3.152.

24. Sjödin B, Jacobs I. Onset of blood lactate accumulation and marathon running performance. Int J Sports Med. 1981;2(1):23-6, http://dx.doi.org/10.1055/s-2008-1034579.

25. Shin YO, Lee JB. Leukocyte chemotactic cytokine and leukocyte subset responses during ultra-marathon running. Cytokine. 2012;61(2):364-9, http://dx.doi.org/10.1016/j.cyto. 2012.11.019.

26. Skinner ER, Watt C, Maughan RJ. The acute effect of marathon running on plasma lipoproteins in female subjects. Eur J Appl Physiol Occup Physiol. 1987;56(4):451-6, http:// dx.doi.org/10.1007/BF00417774.

27. Wu HJ, Chen KT, Shee BW, Chang HC, Huang YJ, Yang RS. Effects of $24 \mathrm{~h}$ ultra-marathon on biochemical and hematological parameters. World J Gastroenterol. 2004;10(18):2711-4.

28. Waśkiewicz Z, Kłapcińska B, Sadowska-Krępa E, Czuba M, Kempa K, Kimsa E, et al. Acute metabolic responses 
to a 24-h ultra-marathon race in male amateur runners.

Eur J Appl Physiol. 2012;112(5):1679-88, http://dx.doi. org/10.1007/s00421-011-2135-5.

29. Kłapcińska B, Waśkiewicz Z, Chrapusta SJ, SadowskaKrępa E, Czuba M, Langfort J. Metabolic responses to a 48-h ultra-marathon run in middle-aged male amateur runners. Eur J Appl Physiol. 2013;113(11):2781-93, http:// dx.doi.org/10.1007/s00421-013-2714-8.

30. Smith JE, Garbutt G, Lopes P, Pedoe D. Effects of prolonged strenuous exercise (marathon running) on biochemical and hematological markers used in the investigation of patients in the emergency department. $\mathrm{Br}$ J Sports Med. 2004;38(3):292-4, http://dx.doi.org/10.1136/ bjsm.2002.002873.

31. Batterham AM, Hopkins WG. Making meaningful inferences about magnitudes. Int J Sports Physiol Perform. 2006;1:50-7.

32. Weight LM, Alexander D, Jacobs P. Strenuous exercise: Analogous to the acute-phase response? Clin Sci. 1991;81:677-83.
33. Szygula Z. Erythrocytic system under the influence of physical exercise and training. Sports Med. 1990;10(3):181-97, http://dx.doi.org/10.2165/00007256-199010030-00004.

34. Lindinger MI. Potassium regulation during exercise and recovery in humans: Implications for skeletal and cardiac muscle. J Mol Cell Cardiol. 1995;27:1011-22, http://dx.doi. org/10.1016/0022-2828(95)90070-5.

35. Sahlin K, Broberg S. Release of $\mathrm{K}^{+}$from muscle during prolonged dynamic exercise. Acta Physiol Scand. 1989;136: 293-4, http://dx.doi.org/10.1111/j.1748-1716.1989.tb08666.x.

36. Mastaloudis A, Leonard SW, Traber NG. Oxidative stress in athletes during extreme endurance exercise. Free Radic Biol Med. 2001;31:911-22, http://dx.doi.org/10.1016/S08915849(01)00667-0.

37. Finaud J, Lac G, Filaire E. Oxidative stress: Relationship with exercise and training. Sports Med. 2006;36:327-58, http://dx.doi.org/10.2165/00007256-200636040-00004.

38. Westerblad H, Allen DG. Emerging roles of ROS/RNS in muscle function and fatigue. Antioxid Redox Signal. 2011;15:2487-99, http://dx.doi.org/10.1089/ars.2011.3909.

This work is available in Open Access model and licensed under a Creative Commons Attribution-NonCommercial 3.0 Poland License - http://creativecommons.org/ licenses/by-nc/3.0/pl/deed.en. 